\title{
Discovery of Compound A - a selective activator of the glucocorticoid receptor with anti-inflammatory and anti-cancer activity
}

\author{
Ekaterina Lesovaya ${ }^{1}$, Alexander Yemelyanov ${ }^{2}$, Amanda C. Swart ${ }^{3}$, Pieter Swart ${ }^{3}$, \\ Guy Haegeman ${ }^{4}$, Irina Budunova ${ }^{5}$ \\ ${ }^{1}$ Department of Chemical Carcinogenesis, N.N. Blokhin Russian Cancer Research Center, Moscow, Russia \\ ${ }^{2}$ Pulmonary Division, Feinberg School of Medicine, Northwestern University, Chicago, IL, USA \\ ${ }^{3}$ Department of Biochemistry, Stellenbosch University, Stellenbosch, South Africa \\ ${ }^{4}$ LEGEST, University of Ghent, Ghent, Belgium \\ ${ }^{5}$ Department of Dermatology, Feinberg School of Medicine, Northwestern University, Chicago, IL, USA \\ Correspondence to: \\ Irina Budunova, e-mail: i-budunova@northwestern.edu \\ Keywords: Review, compound A, selective glucocorticoid receptor activator (SEGRA), inflammation, cancer, autoimmune diseases \\ Received: June 05, 2015 \\ Accepted: September 19, 2015 \\ Published: October 02, 2015
}

\section{ABSTRACT}

Glucocorticoids are among the most effective anti-inflammatory drugs, and are widely used for cancer therapy. Unfortunately, chronic treatment with glucocorticoids results in multiple side effects. Thus, there was an intensive search for selective glucocorticoid receptor (GR) activators (SEGRA), which retain therapeutic potential of glucocorticoids, but with fewer adverse effects. GR regulates gene expression by transactivation (TA), by binding as homodimer to gene promoters, or transrepression (TR), via diverse mechanisms including negative interaction between monomeric GR and other transcription factors. It is well accepted that metabolic and atrophogenic effects of glucocorticoids are mediated by GR TA. Here we summarized the results of extensive international collaboration that led to discovery and characterization of Compound $A$ (CpdA), a unique SEGRA with a proven "dissociating" GR ligand profile, preventing GR dimerization and shifting GR activity towards TR both in vitro and in vivo. We outlined here the unusual story of compound's discovery, and presented a comprehensive overview of CpdA ligand properties, its anti-inflammatory effects in numerous animal models of inflammation and autoimmune diseases, as well as its anti-cancer effects. Finally, we presented mechanistic analysis of CpdA and glucocorticoid effects in skin, muscle, bone, and regulation of glucose and fat metabolism to explain decreased CpdA side effects compared to glucocorticoids. Overall, the results obtained by our and other laboratories underline translational potential of $\mathrm{CpdA}$ and its derivatives for treatment of inflammation, autoimmune diseases and cancer.

\section{INTRODUCTION}

Synthetic glucocorticoids (Gcs) are the most frequently prescribed anti-inflammatory drugs, and have been used worldwide in the treatment of asthma, rheumatoid arthritis, inflammatory bowel disease, psoriasis, and other inflammatory and autoimmune diseases since early 1960s [1-3]. They are also extensively used as immunosupressants in the clinical management of organ transplantation, and as anti-cancer drugs, especially for the treatment of patients with hematological malignancies (leukemia, lymphoma, multiple myeloma).

Unfortunately chronic treatment with Gcs is associated with multiple adverse effects, including altered glucose metabolism, steroid-induced diabetes, osteoporosis, skin and muscle atrophy, alteration of behavior and mood. These clinical conditions motivated the active development of selective GR activators (SEGRA), novel glucocorticoid receptor (GR) ligands that preserve the therapeutic activity of Gcs, with fewer 
adverse effects. Many candidate SEGRA molecules have been synthesized by industry and academia or identified by chemical library screening, with some, such as Mapracorat and PF-04171327, having reached clinical trials [4-10].

This review is focused on Compound A (CpdA), a non-steroidal SEGRA, which is a stable synthetic analogue of a natural compound found in Salsola tuberculatiformis Botschantzev (Fig. 1). We discuss the unusual history of CpdA discovery, its GR ligand properties, antiinflammatory and anti-cancer effects along with decreased metabolic and atrophogenic side effects, as compared to classical Gcs.

\section{DISCOVERY OF COMPOUND A}

Plants belonging to the genus Salsola (Family: Chenopodiaceae) are found in the arid and semi-arid regions of our planet with more than 60 different Salsola species found in Namibia and in the Republic of South Africa [11]. This genus is first mentioned in San folklore as traditional medicinal plants with Salsola aqueous extracts being used as oral contraceptives by San women [12]. During the investigation of the unusual biological effects of Salsola, it was confirmed that at least one member of this genus indeed contains active contraceptive compound(s). The chemical nature of these natural products has however, baffled scientists over many years.

In 1961 de Lange described a rare syndrome of prolonged gestation which sporadically occurred among Karakul sheep in the Keetmanshoop district in Namibia [13]. Salsola tuberculata, later renamed Salsola tuberculatiformis Botschantzev was subsequently identified to be responsible for this syndrome [14] [15]. This shrub is also known to local inhabitants as "gannabos". In our investigations, using various derivatizing reagents to isolate the labile compounds in the form of their stabilized derivatives, we showed that treatment with trimethylammonium acetyl hydrazide chloride (Girard-T reagent), used for the isolation of aldehydes and ketones [16], removed all the contraceptive activity from active plant extracts [17]. The derivatives formed in this manner were isolated by solvent partitioning and then decomposed under acidic conditions to yield three compounds in pure form (Fig. 1A-1C). These compounds were identified by proton NMR and EI-mass spectrometry as 4-hydroxy-acetophenone (Fig. 1A), 4-hydroxy-3-methoxy- acetophenone (Fig. 1B) and 4-hydroxy-benzaldehyde (Fig. 1C) [17]. Although synthetic samples of both ketones did show some biological activity
A<smiles>CC(=O)c1ccc(O)cc1</smiles>

4-hydroxy-acetophenone
B<smiles>COc1cc(C(C)=O)ccc1O</smiles>

4-hydroxy-3-methoxy-acetophenone
C<smiles>O=Cc1ccc(O)cc1</smiles>

4-hydroxy-benzaldehyde
D<smiles>C[NH2+]CC(O)c1ccc(O)cc1</smiles>

\section{[2-hydroxy-2-(4-hydroxy-phenyl)- ethyl]-methyl-ammonium chloride (synephrine)}

E<smiles>C[NH2+]CC(Cl)c1ccc(OC(C)=O)cc1</smiles>

Figure 1: Chemical structures of selected phenolic compounds from S. tuberculatiformis, and their synthetic analog, Compound A. A-C. Chemical structures of selected bio-active phenolic compounds isolated from S. tuberculatiformis Botch extracts, D. an inactive compound, [2-(hydroxy)-2-(4-hydroxyphenyl)-ethyl]-methyl ammonium chloride (synephrine), and E. a synthetic analog 2-(4-acetoxyphenyl)-2-chloro-N-ethyl ammonium chloride (Compound A). See also [111] for additional details. 
in rats, neither $\mathrm{A}$ or $\mathrm{B}$, nor a mixture of $\mathrm{A}+\mathrm{B}$, could, at the levels found in the extract, account for the contraceptive activity of the plant. The aldehyde (Fig. 1C) was inactive. In later experiments without derivatizing reagents, we were able to isolate another pure compound which consistently appeared in active fractions. The compound was identified by NMR, UV and EI-mass spectrometry as 1-(4- hydroxy phenyl)-2-methyl-aminoethanol or synephrine (Fig. 1D). This structure was subsequently confirmed by spectroscopic comparison with synthetic compounds as well as by the preparation of the same acylated derivatives from natural and synthetic material. Synthetic synephrine did not, however, show biological activity similar to that of the active plant extract.

These data suggested that compounds identified in active Salsola extracts probably arose as breakdown products from one or more, yet unknown, active precursor(s), pointing to the presence of phenolic compound(s) that contained a labile functional group. The labile group apparently decomposed under appropriate conditions to aldehydes, ketones or alcohols. Our results further suggested that the long duration of the biological tests for contraceptive activity was not compatible with the testing of the active compound(s), necessitating a more rapid and sensitive screening method for the evaluation of plant extracts or fractions. We developed a micro-assay based on the interference of the test compound with the substrate-induced difference spectrum of sheep adrenal cytochrome P450-dependent steroid 11 $\beta$-hydroxylase (CYP11B1), the enzyme catalyzing the biosynthesis of cortisol and corticosterone from deoxycortisol and deoxycorticosterone, respectively [18-21]. We isolated a single compound to homogeneity using this assay and named it S2 [21]. Structure determination by NMR and mass spectrometry indicated the presence of an unstable aziridine, after which we subsequently synthesized a more stable aziridine precursor, Compound A (CpdA, Fig. 1E).

We showed that CpdA, similar to extracts prepared from dried plant material, caused contraception in rats [20] and interacted with two glucocorticoid-binding proteins: CYP11B1 and corticosteroid-binding globulin in plasma $(\mathrm{CBG})$, while also being able to displace Gcs from $\mathrm{CBG}$ [22]. The fact that CpdA interacted with Gcsbinding proteins, suggested that it could also bind to GR, a well known transcription factor (TF) that mediates the biological effects of glucocorticoid hormones [23-25].

\section{COMPOUND A ACTS AS A SELECTIVE GR ACTIVATOR (SEGRA) AND AN ANTAGONIST OF THE ANDROGEN RECEPTOR}

The GR belongs to a superfamily of nuclear hormone receptors and shares a characteristic threedomain structure: a variable $\mathrm{N}$-terminal region with transactivation domain responsible for gene activation, a conserved central DNA-binding domain with dimerization and nuclear localization sequences, and a conserved C-terminal ligand-binding domain [26-29].

In the absence of Gcs, the GR resides in cytoplasm bound to chaperones: heat shock proteins and immunophillins that control GR nuclear import [30, 31]. Upon Gcs binding, the GR translocates to the nucleus, where it regulates gene expression via (i) transactivation (TA), that requires GR-homodimer binding to palindromic glucocorticoid-responsive elements (GRE), and (ii) transrepression (TR), mediated via different mechanisms including negative interaction between GR and other TFs, such as NF- $\mathrm{kB}$, AP-1, p53, STATs, IRF-3, CREB [12, 26-28, 32-34]. This interaction may occur in the nucleus or, as we have reported, in the cytoplasm [35], and does not require GR dimerization, as it could be mediated by the monomeric GR [26-28, 33, 36].

We and others reported that CpdA acts as a GR ligand. It binds to the GR with high affinity, with $\mathrm{IC}_{50}$ in the $\mathrm{nM}$ range, as determined by competitive ligandbinding assays in human and rodent cells expressing endogenous GR [35-37]. The effects of CpdA on major steps of GR activation: phosphorylation, dimerization, nuclear translocation and GR-DNA binding have been extensively studied. We showed, in fibroblasts, epithelial and lymphoid cells with endogenous or exogenous GR, that CpdA induced modest GR nuclear translocation [35, 37, 39]. Using different approaches including fluorescence resonance energy transfer (FRET), we and others discovered that CpdA, unlike Gcs, did not elicit ligandinduced GR dimerization [35-38]. Furthermore, CpdA did not induce GR phosphorylation at Ser211, critical for GR TA activity [37]. Consequently, CpdA did not significantly affect or even inhibited constitutive and Gcs-induced GR DNA binding and activation of endogenous genes and GRE.Luciferase reporters [35-37, 39]. In contrast, CpdA and classical Gcs have remarkably similar TR profiles, suppressing the activity of many pro-proliferative and anti-apoptotic TFs. Depending on cell context, CpdA has been shown to inhibit NF- $\mathrm{B}$, AP-1, Ets-1, Elk-1, SRF, NFATc [35, 37, 39]. Using cells with GR knockdown or lacking GR, we proved that CpdA inhibitory effects on TFs are GR-dependent [35, 37, 39]. Interestingly, in contrast to Ges that usually do not interfere with TF nuclear translocation, CpdA significantly decreased/ delayed nuclear import of NF-kB and AP-1 proteins $[35,40]$.

The global effect of CpdA and the glucocorticoids on gene expression was compared by DNA array analyses in A549 lung carcinoma and Granta-519 lymphoma cells with endogenous GR; and in prostate cancer LNCaP-GR cells stably expressing exogenous GR. In both, epithelial and lymphoid cells, molecular TA signatures of CpdA and the synthetic glucocorticoid, dexamethasone (Dex), were different. In fact, CpdA was able to activate only $7-11 \%$ of the genes induced by Dex in LNCaP-GR and Granta-519 cells (Fig. 2). However, their effects on the GR TR branch 
were much more similar - CpdA was able to inhibit the expression of $31 \%$ and $66 \%$ of genes negatively regulated by Dex in lymphoma and prostate cancer cells, respectively (Fig. 2), and suppressed 32\% of the genes negatively regulated by Dex in A549 lung cells [41]. In summary, our validated microarray results (Supplementary Fig. 1, Supplementary Tables S1 and S2; NCBI arrays with access numbers GSE71102 (LNCaP-GR) and GSE71099 (Granta-519) confirmed at global level the unique CpdA capability to dissociate GR TA and TR functions, and to shift GR function towards TR.

In addition to its function as a SEGRA, CpdA acts as an antagonist of the androgen receptor (AR). Even though CpdA has a lower affinity for the AR compared to active androgens, CpdA induced considerable AR nuclear translocation $[35,42]$. We and others showed that CpdA repressed the interaction between the $\mathrm{NH}(2)$ - and $\mathrm{COOH}-$ terminal domains of the AR critical for its function, and inhibited both constitutive and dihydrotestosterone (DHT)induced AR-DNA binding and AR transcription activity in Luciferase reporter assays $[35,42]$. These results suggest that the interaction of CpdA with the AR closely resembles the effects of well characterized anti-androgens, such as Casodex. CpdA did not significantly affect the activity of other steroid hormone receptors such as mineralcorticoid, progesterone, and estrogen receptors [36, 37].

It is important to note that $\mathrm{CpdA}$ is also characterized by its own molecular signature component, and regulated a subset of genes that were not affected by Gcs ([41], GEO submissions GSE71102 and GSE71099). Whether these genes were regulated via GR/AR remains to be investigated. Nevertheless, the therapeutic activity of CpdA was mostly mediated via GR or AR steroid receptors as discussed below.

\section{THE BIOLOGICAL ACTIVITY OF CPDA- POTENTIAL CLINICAL BENEFITS}

Our findings have contributed to the understanding of the significance of GR TR mechanisms in the antiinflammatory and anti-cancer effects of Gcs [43-46]. In contrast, GR TA is proposed to underlie many adverse metabolic effects of Gcs [46-50]. Even though some genes activated by Gcs (such as DUSP1/MKP1, GILZ, I $K B a$ ) are involved in anti-inflammatory responses, while other genes inhibited by Gcs/GR (adrenocorticotropic hormone $(A C T H)$ or collagens) are involved in steroidal side effects, it is now well established in the field that GR ligands,

\section{A. LNCaP-GR cells}
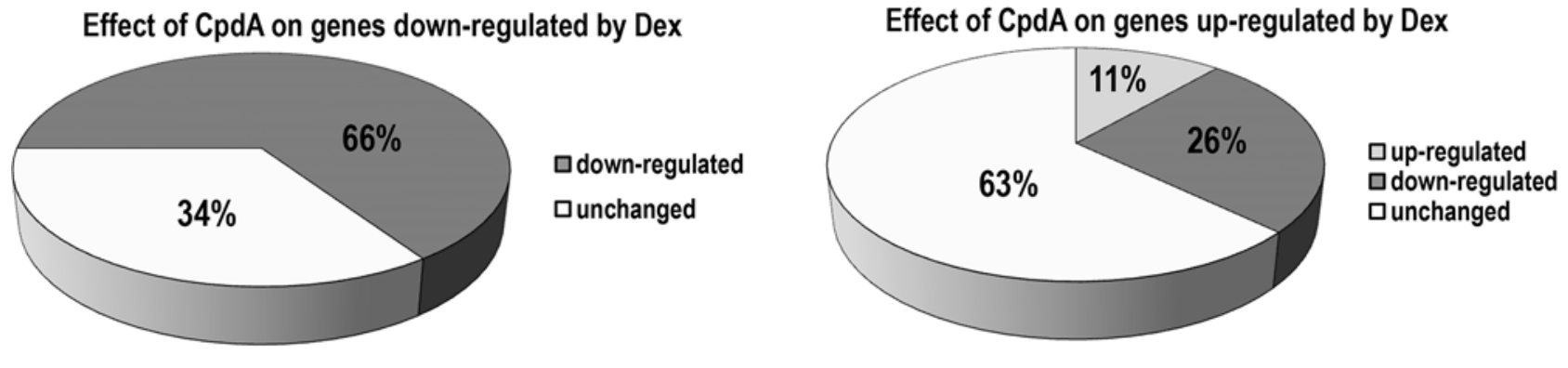

\section{B. Granta- 519 cells}

Effect of $\mathrm{CpdA}$ on genes down-regulated by Dex

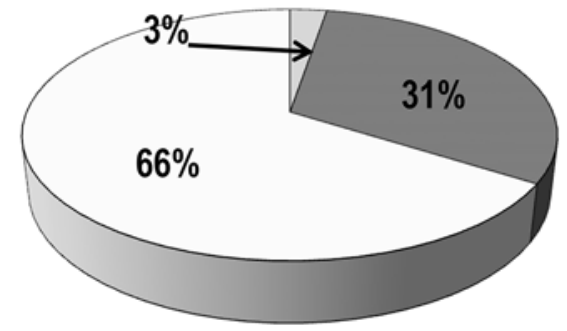

Effect of $\mathrm{CpdA}$ on genes up-regulated by Dex

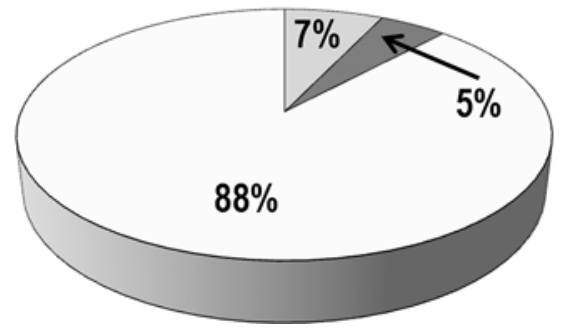

口up-regulated $\square$ down-regulated cup-regulated 口unchanged

Figure 2: Global CpdA effect on the expression of glucocorticoid-responsive genes in epithelial and lymphoid cells. A. LNCaP-GR cells were treated with vehicle (EtOH), glucocorticoid Dexamethasone (Dex, $1 \mathrm{uM})$ or CpdA (5 uM) for $8 \mathrm{~h}$; B. Granta-519 cells expressing endogenous GR, were treated with vehicle, Dex (1 uM) or CpdA ( $1 \mathrm{uM})$ for 16 h. Total RNA was extracted, and global gene expression changes were evaluated by Illumina DNA arrays (three individual RNA samples/group). Expression changes with fold change $>1.5$, and $p$-value $<0.05$ were considered biologically and statistically significant. Effect of CpdA on Dex-regulated genes: down-regulation (black); up-regulation (grey), no change (white). 
which do not support GR dimerization and predominantly activate the TR branch of GR signaling, should have a better therapeutic index than classical Gcs [36, 50-52]. Indeed, it is believed that GR ligands that "dissociate" GR TR from GR TA will retain the therapeutic activity of classical steroids, but will have reduced adverse side effects regarding bone, glucose and lipid metabolism. Thus, based on its GR ligand profile, CpdA was expected to exert pronounced anti-inflammatory and anti-cancer effects, while inducing fewer adverse effects typical for the classical synthetic Ges that often limit their therapeutic applications. As discussed below, we had also anticipated that, compared to Gcs, CpdA would be less likely to induce patient resistance to GR-targeted therapy $[39,106]$.

\section{Anti-inflammatory effects of compound A}

Gcs remain a gold standard as anti-inflammatory drugs. They are effective against a wide range of inflammatory and autoimmune diseases characterized by the different types of CD4+ T helper (Th) lymphocytes. Th1 cells producing interferon (IFN)- $\alpha$, interleukin (IL)-2, transcription factor T-bet, and tumor necrosis factor (TNF), as well as Th17 cells producing IL-17, are all implicated in the pathogenesis of autoimmune disorders including multiple sclerosis, rheumatoid arthritis, diabetes mellitus type 1 ; inflammatory bowel disease (Crohn's disease) and acute organ rejection [53-61]. Th2 cells that produce IL-4, IL-5, IL-6, IL-9, IL-10, and IL-13 are mostly responsible for atopic disorders (such as atopic dermatitis, rhinitis, asthma), and allergies [54-60]. It is well known that Ges can block both Th1/Th17 and Th2 inflammatory responses as well as inflammatory factors, such as NF- $\mathrm{BB}$, central for the production of cytokines and chemokines involved in the activation and differentiation of Th cells.

The therapeutic activity of CpdA was extensively tested in comparison with Gcs by us and other research groups in various Th1/Th17 and Th2 in vivo models of inflammation (Table 1). In the Th1/Th17 models, which included zymozan paw inflammation, collagen-induced arthritis (CIA), experimental autoimmune neuritis (EAN) and encephalomyelitis (EAE), type 1 diabetes and acute colitis, CpdA inhibited the development of clinical symptoms and morphological manifestations of disease, such as paw swelling, inflammation in joints, colon, pancreas, central nerve system and peripheral nerves $[37$, 38, 62-66]. CpdA also reduced neuronal damage and demyelination, as well as progression of neuropathic pain [65]. Furthermore, in the predominantly Th2-driven mouse asthma model, CpdA reduced inflammation and airway hyper-responsiveness [66]. In all the aforementioned models, CpdA decreased both the severity of localized clinical symptoms and the systemic signs of inflammation. However, CpdA doses in most studies were $\sim 10$-fold higher compared to Gcs, possibly due to a lower GR affinity and the non-steroidal nature of the compound $[26,33,37]$.
CpdA has also been shown to ameliorate muscle pathology in $m d x$ mice, an animal model for Duchene muscular dystrophy associated with abnormal muscle inflammation and activation of NF- $\kappa \mathrm{B}$. CpdA treatment for a period of 2 months, normalized limb strength and function and attenuated cathepsin-B enzyme activity (a surrogate marker for inflammation) [67].

\section{Mechanisms of the anti-inflammatory effects of $\mathrm{CpdA}$}

At molecular level, the anti-inflammatory effects of CpdA were mediated mostly through blockage of inflammatory TFs including NF- $\mathrm{B}$, T-bet, STAT6, the latter being central to the Th2-driven asthma model [61, $66,68]$, which resulted in strong inhibition of expression of numerous pro-inflammatory cytokines and chemokines characteristic for each specific model. For example, in the zymosan-induced paw inflammation model, the antiinflammatory effect of $\mathrm{CpdA}$ was associated with the down-regulation of TNF- $\alpha$-induced- and NF- $\kappa \mathrm{B}$-dependent pro-inflammatory genes such as $I L-6$, E-selectine, $I L-8$ and others [37]. In the model of experimental colitis induced by trinitrobenzene sulfonic acid, CpdA reduced the production of colonic $T N F-\alpha, I L-1$, and $C O X-2$ at mRNA level [69].

In models of autoimmune diseases such as arthritis, experimental autoimmune encephalomyelitis (EAE), autoimmune neuritis (EAN), and asthma, CpdA inhibited the expression of both Th1/Th17 and Th2 cytokines [38, 62-66, 70-72]. In mice with EAE, for instance, CpdA was able to penetrate the blood-brain barrier and attenuated EAE symptoms via the inhibition of $N F-\kappa B$ nuclear translocation and the expression of $\mathrm{NF}-\kappa \mathrm{B}$-driven proinflammatory cytokines (INF- $\gamma ; I L-1 \beta ; T N F-\alpha$; IL-23; $I L-17$ and others) in the central nerve system [63]. In the Th2 asthma model, CpdA's effects were mediated by the inhibition of TNF- $\alpha$ and Th2 inflammatory cytokines $(I L-4, I L-5, I L-6)$ as well as blockage of NF- $\mathrm{B}$ activity in lung [66]. In the model of Duchene muscular dystrophy, CpdA reduced expression of $I L-6, C C L 2, I F N \gamma, T N F-\alpha$, and $I L-12 p 70$ cytokines in muscle [67]. Interestingly, in models of inflammatory type 1 diabetes and autoimmune neuritis, CpdA, in addition to its inhibitory effect on Th1/Th17 cytokines, was able to switch Th1/Th17 differentiation towards anti-inflammatory $\mathrm{T}$ regulatory (Treg) cell differentiation, an important mechanism for the resolving of inflammation $[65,73]$.

The molecular mechanisms of CpdA effects on $\mathrm{NF}-\kappa \mathrm{B}$ activation and the expression of inflammatory cytokines have been further corroborated in vitro, in cell lines and in primary cell cultures including mouse microglia and astrocytes, as well as synoviocytes from patients with rheumatoid arthritis $[63,70]$. In most experiments, cells were activated by TNF- $\alpha$ or LPS to induce cytokine expression. Alternatively, HepG2 human liver cells were infected with Dengue virus to induce inflammatory cytokines and to model the "cytokine storm" that underlies the pathogenesis of Dengue hemorrhagic 
Table 1: Anti-inflammatory effects of CpdA

\begin{tabular}{|c|c|c|c|}
\hline Model description & Therapeutic effects of CpdA & Possible molecular mechanisms & References \\
\hline \multicolumn{4}{|c|}{ In vivo models of inflammation } \\
\hline $\begin{array}{l}\text { Zymozan-induced } \\
\text { inflamed paw }\end{array}$ & Decreased swelling & $\begin{array}{l}\text { Decreased NF- } \mathrm{\kappa B} \text { activity and inhibited } \\
\text { expression of pro-inflammatory cytokines: } I L-8 \text {, } \\
I L-6 \text {, and } E \text {-selectin }\end{array}$ & {$[37]$} \\
\hline $\begin{array}{l}\text { Collagen-induced } \\
\text { arthritis }\end{array}$ & $\begin{array}{l}\text { Decreased severity of disease; } \\
\text { Strong anti-inflammatory } \\
\text { response }\end{array}$ & $\begin{array}{l}\text { Inhibited TNF- } \alpha \text {-induced production of pro- } \\
\text { inflammatory cytokines: IL- } 1 \beta \text {, IL- } 6\end{array}$ & $\begin{array}{l}{[70],[38]} \\
{[62]}\end{array}$ \\
\hline $\begin{array}{l}\text { Experimental } \\
\text { autoimmune } \\
\text { encephalomyelitis }\end{array}$ & $\begin{array}{l}\text { Ameliorated clinical symptoms } \\
\text { and disease severity; Reduced } \\
\text { leukocyte infiltration in the spinal } \\
\text { cord; Reduced neuronal damage } \\
\text { and demyelination }\end{array}$ & $\begin{array}{l}\text { Impaired NF- } \kappa \mathrm{B} \text { activation; } \\
\text { Inhibited pro-inflammatory cytokines: INF- } \alpha \text {, IL- } \\
1 \beta, \text { TNF- } \alpha \text {, IL-23, IL-17 }\end{array}$ & {$[63] ;[64]$} \\
\hline $\begin{array}{l}\text { Experimental } \\
\text { autoimmune neuritis }\end{array}$ & $\begin{array}{l}\text { Inhibited paraparesis; Decreased } \\
\text { infiltration of sciatic nerves with } \\
\text { lymphocytes and macrophages } \\
\text { and the progression of } \\
\text { neuropathic pain; Decreased } \\
\text { demyelination; } \\
\text { Modulated immune response: } \\
\text { switch from Th1/Th17 towards } \\
\text { anti-inflammatory T regulatory } \\
\text { (Foxp3+/CD4+ Treg) response }\end{array}$ & $\begin{array}{l}\text { Inhibited Th1/Th17 cytokines in microglia: } I L 1 \beta \text {, } \\
I L-17, I L-12 p 35, I F N-\gamma, T N F-\alpha \text {, and } i N O S \text {; } \\
\text { Increased Th2 cytokine and Foxp3 expression. }\end{array}$ & {$[65]$} \\
\hline $\begin{array}{l}\text { Acute trinitrobenzene } \\
\text { sulfonic acid-induced } \\
\text { colitis }\end{array}$ & $\begin{array}{l}\text { Ameliorated acute colitis; } \\
\text { Inhibited inflammatory cell } \\
\text { infiltration into colon wall }\end{array}$ & $\begin{array}{l}\text { Inhibited expression of pro-inflammatory genes: } \\
\text { TNF- } \alpha \text {, IL- } 1 \beta \text {, and COX-2 }\end{array}$ & {$[69]$} \\
\hline $\begin{array}{l}\text { Streptozotocin model } \\
\text { of type } 1 \text { diabetes }\end{array}$ & $\begin{array}{l}\text { Protected against development of } \\
\text { diabetes; } \\
\text { Modulated peripheral immune } \\
\text { response (switch from Th1/Th17 } \\
\text { towards anti-inflammatory T } \\
\text { regulatory/ Treg response) }\end{array}$ & $\begin{array}{l}\text { Inhibited pro-inflammatory cytokines: IL-1 } \beta \text {, } \\
\text { TNF- } \alpha \text {, IL-6; } \\
\text { Up-regulated expression of anti-inflammatory } \\
\text { cytokines: IL-4 and IL-10 }\end{array}$ & {$[73]$} \\
\hline $\begin{array}{l}\text { Ovalbumin-induced } \\
\text { Th2-driven asthma } \\
\text { model }\end{array}$ & $\begin{array}{l}\text { Reduced inflammatory cell } \\
\text { infiltration in lungs, cytokine } \\
\text { production, mucus and Ig } \\
\text { production; } \\
\text { Reduced development of airway } \\
\text { hyperresponsiveness (AHR) }\end{array}$ & $\begin{array}{l}\text { Inhibited NF- } \kappa \mathrm{B} \text { activity and nuclear } \\
\text { translocation; } \\
\text { Inhibited STAT6 activity and nuclear } \\
\text { translocation; } \\
\text { Inhibited expression of Th2 cytokines: } I L-4, I L-5 \text {, } \\
\text { and } I L-13\end{array}$ & {$[66]$} \\
\hline $\begin{array}{l}m d x \text { (Dystrophin- } \\
\text { deficient) mice, an } \\
\text { animal model for } \\
\text { Duchene muscular } \\
\text { dystrophy }\end{array}$ & $\begin{array}{l}\text { Reduced muscle inflammation; } \\
\text { Improved strength and function } \\
\text { of the limbs }\end{array}$ & $\begin{array}{l}\text { Inhibited NF- } \kappa \text { B signaling in muscle; Inhibited } \\
\text { expression of IL- } 6, \text { CCL2, IFN- } \gamma \text {, TNF- } \alpha \text {, IL- } \\
12 \text { p70 }\end{array}$ & [67] \\
\hline \multicolumn{4}{|c|}{ In vitro models of inflammation } \\
\hline $\begin{array}{l}\text { Synovial fibroblasts } \\
\text { from patients with } \\
\text { rheumatoid arthritis }\end{array}$ & & $\begin{array}{l}\text { Inhibited NF- } \kappa \mathrm{B} \text { activity and IKK } \\
\text { phosphorylation; } \\
\text { Induced I } \kappa-\alpha \text { accumulation; Inhibited } I L-1 \beta \\
\text { expression }\end{array}$ & $\begin{array}{l}{[106]} \\
{[38]} \\
{[70]}\end{array}$ \\
\hline
\end{tabular}

(Continued) 


\begin{tabular}{|c|c|c|c|}
\hline Model description & Therapeutic effects of CpdA & Possible molecular mechanisms & References \\
\hline $\begin{array}{l}\text { Co-cultivation of } \\
\text { BMSC (bone marrow } \\
\text { stem cells) with } \\
\text { osteoclasts }\end{array}$ & & $\begin{array}{l}\text { Inhibited } I L-1 \beta, T N F-\alpha, I L-6 \\
\text { expression }\end{array}$ & [105] \\
\hline $\begin{array}{l}\text { Dengue virus } \\
\text { (DENV) infection of } \\
\text { HepG2 transformed } \\
\text { hepatocyte cells }\end{array}$ & Reduced DENV production & $\begin{array}{l}\text { Reduced the expression of DENV-induced } \\
\text { cytokines: CXCL10 and TNF- } \alpha \text {; } \\
\text { Decreased leukocyte migration }\end{array}$ & [74] \\
\hline $\begin{array}{l}\text { Murine } \\
\text { T-lymphocytes }\end{array}$ & & $\begin{array}{l}\text { Inhibited T-bet (T box expressed in T-cells) } \\
\text { factor central for Th1 response; Decreased GR- } \\
\text { dependent transrepression }\end{array}$ & [61] \\
\hline $\begin{array}{l}\text { Primary microglial } \\
\text { cells }\end{array}$ & & $\begin{array}{l}\text { Inhibited NF- } \kappa \mathrm{B} \text { activation; Inhibited } T N F-\alpha \text { and } \\
I L-1 \beta \text { cytokines }\end{array}$ & [63] \\
\hline $\begin{array}{l}\text { Immortalized murine } \\
\text { macrophage cell line } \\
\text { RAW } 264.7\end{array}$ & & $\begin{array}{l}\text { Attenuated expression of } T N F-\alpha, i N O S \text {, and } I L-1 \text {, } \\
\text { but increased expression of anti-inflammatory } \\
I L-10 \text {; } \\
\text { Induced macrophage differentiation towards M2 } \\
\text { anti-inflammatory phenotype }\end{array}$ & [65] \\
\hline
\end{tabular}

fever [74]. The aforementioned experiments demonstrated that CpdA inhibited NF- $\kappa \mathrm{B}$ and the expression of proinflammatory cytokines in a GR-dependent fashion, and confirmed that CpdA acts as "dissociated" GR ligand, as it was incapable of activating GR target genes, such as DUSP1/MKP1, GILZ, FKBP51 [38, 62, 65, 69, 70]. Interestingly, in vitro experiments confirmed that CpdA, in contrast to Gcs, can do both: inhibit expression of inflammatory cytokines and induce the expression of antiinflammatory cytokines such as IL-10 [65].

\section{Anti-cancer effects of Compound $A$ as a mono- therapy and in combination with proteasome inhibitors}

Gcs usually promote cell differentiation and inhibit proliferation, and have proven anti-cancer activity $[44,45,75,76]$. Synthetic Gcs have been extensively used clinically against leukemia, lymphomas, and multiple myeloma. The steroids are typically paired with traditional chemotherapies (cyclophosphamide, doxorubicin, vincristine, methotrexate), and newer (proteasome inhibitors) agents [77-80]. Gcs are also used in combination therapy of patients with epithelial cancers, mostly for palliative treatment of metastasis-related pain, decreasing nausea and other side effects of chemotherapy [81]. However, in some cases they have been used as anticancer drugs, and even as a mono-therapy, as in the case of elderly patients with prostate cancer [82].

In contrast to anti-inflammatory effects, the anticancer effects of $\mathrm{CpdA}$ were uncovered more recently. Our findings showed that $\mathrm{CpdA}$ inhibited growth and viability of numerous cancer cells including prostate cancer, lymphoma, leukemia and multiple myeloma as well as melanoma cell lines (Table 2). The anti-cancer effect of CpdA was GR-dependent, and in cancer cells with GR knockdown, CpdA was significantly less toxic (Table 2) $[35,39,83]$. In prostate cancer cell models, the cytotoxic concentrations of $\mathrm{CpdA}$ were in the range of $10^{-5}$ to $10^{-6} \mathrm{M}$, in standard growth and apoptosis tests inmonolayer cultures as well as in colony-forming assays (Fig. 3A and $[35,83])$. Moreover, using prostate cancer cells with different AR and GR status, we demonstrated clearly that CpdA could exert its cytostatic effect via both receptors which correlated with CpdA's dual GR/AR ligand properties shown in our earlier studies [35].

The leukemia and lymphoma cells appeared to be far more sensitive to CpdA than epithelial cancer cells. CpdA was equally or more potent than Gcs in the inhibition of growth and survival of transformed lymphoid cell lines, as well as in primary cell cultures from acute $\mathrm{T}$ cell leukemia patients [39].

We subsequently used human cancer cells xenografts to assess the anti-cancer activity of CpdA in vivo (Figs. $3 \mathrm{~B}$ and $3 \mathrm{C}$ ), and demonstrated that $\mathrm{CpdA}$ inhibited growth of PC3 prostate cancer cell xenografts by $40 \%$ and Granta-519 mantle cell lymphoma xenografts by $70 \%$ when used at doses $\sim 8-10 \mu \mathrm{g} /$ animal, which were lower than the anti-inflammatory doses of CpdA [37, 63].

As mentioned above, Gcs are mostly used in combination anti-cancer therapies, frequently with proteasome inhibitors such as Bortezomib (BZ) - a proteasome inhibitor approved by FDA in 2003 for the treatment of hematological malignancies [84, 85]. While the biological effects of GR ligands depend on GR levels, proteasome inhibitors are known to stabilize the GR and to 
Table 2: Cytotoxic effect of CpdA in cancer cells in vitro

\begin{tabular}{|c|c|c|c|c|}
\hline Cell line & Origin & Effect & CpdA concentration & References \\
\hline RWPE-1 & $\begin{array}{l}\text { Non-transformed prostate } \\
\text { cells }\end{array}$ & $+/-$ & $10 \mathrm{uM}$ & [35] \\
\hline LNCaP-GR & Prostate Cancer (PC) & ++ & $10 \mathrm{uM}$ & {$[35,83]$} \\
\hline PC3 & PC & +++ & $10 \mathrm{uM}$ & [35] \\
\hline DU145 & PC & +++ & $10 \mathrm{uM}$ & [35] \\
\hline Hematopoietic SCs & & - & $10 \mathrm{uM}-50 \mathrm{uM}$ & Budunova et al., unpublished \\
\hline Granta-519 & $\begin{array}{l}\text { Mantle cell lymphoma } \\
\text { (MCL) }\end{array}$ & ++ & $1 \mathrm{uM}$ & [39] \\
\hline NCEB-1 & MCL & +++ & $1 \mathrm{uM}$ & [39] \\
\hline MM-1.S & Multiple myeloma & +++ & $1 \mathrm{uM}$ & [39] \\
\hline CEM & $\mathrm{T}$ cell leukemia & ++ & 3 uM & [39] \\
\hline A375 & Melanoma & ++ & $10 \mathrm{uM}$ & $\begin{array}{c}\text { Yemelyanov and Budunova, } \\
\text { unpublished }\end{array}$ \\
\hline C8161 & Melanoma & ++ & $10 \mathrm{uM}$ & $\begin{array}{c}\text { Yemelyanov and Budunova, } \\
\text { unpublished }\end{array}$ \\
\hline
\end{tabular}

Cancer cells and non-transformed cells of the same origin were treated with CpdA or vehicle, and the cytotoxic effect was evaluated by cell counting as described $[35,39,83]$. The cytotoxic effect is depicted $+(25 \%) /++(30-50 \%) /+++(>50 \%)$ cell number reduction in CpdA versus vehicle control group.
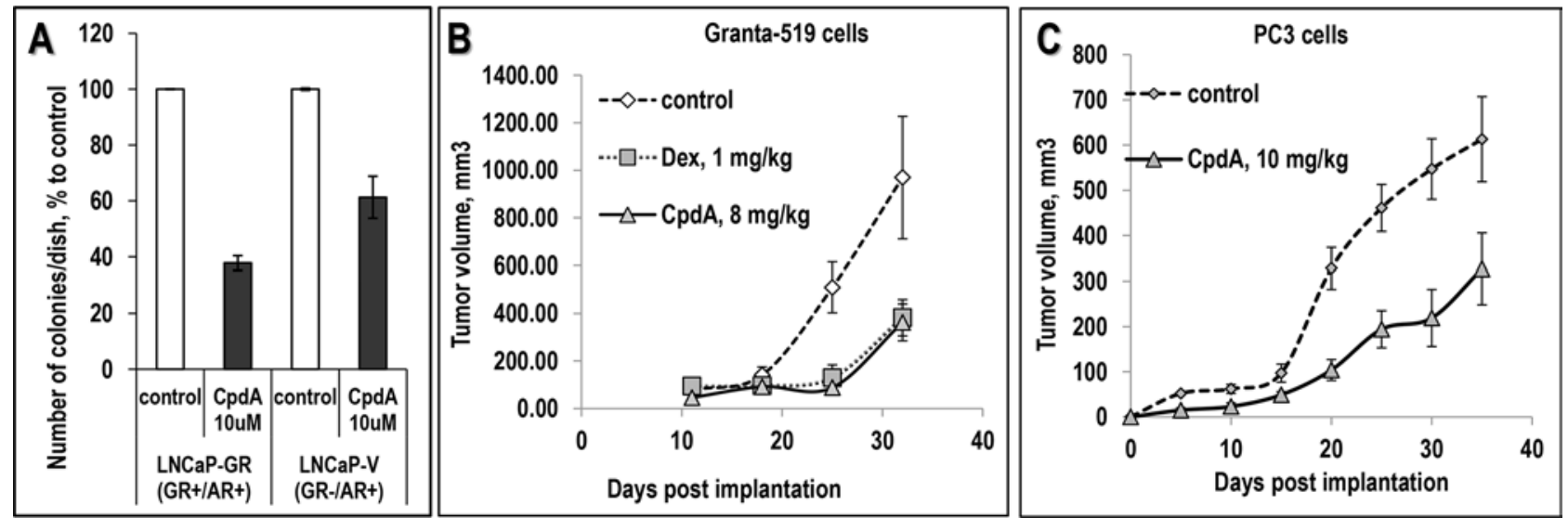

Figure 3: Anti-cancer effect of CpdA in colony forming assay and in xenograft models. A. Inhibitory effect of CpdA on anchorage-independent cell growth. LNCaP-GR and LNCaP-V (empty virus) -infected cells on 1\% soft agar were treated with vehicle or 5 uM CpdA as described ([35], Supplementary Table S3). B, C. Effect of CpdA on prostate cancer cells (PC3) and lymphoma cells (Granta-519) xenograft growth in vivo. Granta-519 cells (B, 10 million cells/site in BD Matrigel Matrix) and PC3 cells (C, 1.2 million cells/ site) were injected s.c. into athymic nu/nu female mice. Mice with established tumors $\left(>50 \mathrm{~mm}^{3}\right)$ were treated by i.p. injections 3 times/wk for 35 days with: CpdA (solid line), Dex (dotted line) or vehicle (0.1\% Etoh in saline, dashed line).

prevent Gcs-induced GR degradation [86, 87]. We showed that BZ indeed induced GR accumulation in lymphoma, leukemia and prostate cancer cells, and enhanced CpdA's profile as a dissociated GR ligand further shifting GR signaling to TR $[35,39,83]$. Moreover, we showed that BZ sensitized lymphoma and prostate cancer cells to CpdA, and we revealed a pronounced GR-dependent cooperative CpdA and BZ anti-cancer effect [35, 39, 83]. Similar results were obtained in multiple myeloma cells MM.1S expressing endogenous functional GR, in which the anti-cancer effects of CpdA and BZ were also synergistic [39].

\section{The mechanisms of anti-cancer effect of $\mathrm{CpdA}$}

There is growing evidence that, in parallel with inhibition of growth and survival, Ges launch an antiapoptotic program and, under certain conditions, can even protect cancer cells from chemotherapy-induced apoptosis [81, 88-91]. We and others have reported that 
Gcs can activate inhibitors of apoptosis IAPs, MAP kinase phosphatase DUSP1/MKP1 (resulting in AP1 inhibition), pro-survival serum and glucocorticoid-inducible protein kinase SGK1, as well as increasing the expression of antiapoptotic genes from the Bcl-2 family ( $\mathrm{Bcl}-2$ and $\mathrm{Bcl}-\mathrm{xl}$ ) $[83,88-90,92]$. In addition, we showed that Ges prevent $\mathrm{BZ}$-induced endoplasmic reticulum (ER) stress in prostate cancer cells [83].

CpdA on the other hand, in contrast to Ges did not induce an anti-apoptotic self-defense program in cancer cells. Moreover, CpdA enhanced lethal BZ-induced ER stress [83]. Our findings highlighted the potential benefits of combining a SEGRA such as CpdA with proteasome inhibitors to trigger the maximal potential of anti-cancer GR signaling.

\section{Cell desensitization to activated GR signaling: CpdA versus glucocorticoids}

Chronic treatment with Gcs frequently result in the development of resistance to steroids (tachyphylaxis) [93], which is in part mediated by the decreased GR levels in the cells. It is known that GR agonists induce the repression of GR transcription as well as the destabilization of the GR at mRNA and protein levels [94]. The inhibition of GR transcription by Gcs is mediated by the recruitment of activated GR to the negative GRE in exon 6 of $G R$, followed by the assembly of a GR-NCoR1-HDAC3 repression complex at the transcriptional start site of the $G R$ gene [94]. Interestingly, CpdA did not induce GR loading in exon 6 (Haegeman and Cidlowski, unpublished data).

Although Gcs also induce GR degradation by proteasome [87], CpdA, in contrast, did not trigger significant GR degradation in lymphoid cells or in synoviocytes $[38,39,70]$. The differential effects of CpdA on crucial steps in GR degradation by the proteasome, such as GR phosphorylation and ubiquitination for example, remain to be investigated.

Another mechanism of cell desensitization common to Gcs is mediated by a negative feedback loop via the GR molecular chaperone FKBP51, also referred to as FK506binding protein 5 [95]. FKBP51 sequesters the GR in the cytoplasm and prevents nuclear translocation [96, 97]. We showed that, in contrast to Gcs, CpdA did not activate FKBP51 gene expression [39, 83].

In summary, our experiments demonstrated that CpdA failed to induce major mechanisms underlying the development of cell resistance to activated GR signaling.

\section{Adverse metabolic and atrophogenic effects: CpdA versus glucocorticoids}

Together with their excellent therapeutic effects, Gcs are notorious for their multiple adverse side effects which develop in different organs and tissues during chronic treatment. The long list of undesirable effects includes changes in glucose and fat metabolism, Cushing's syndrome, diabetes, glaucoma, osteoporosis, muscle and skin atrophy, decreased wound healing, changes in mood and central nervous system functions, growth retardation in pediatric patients, and infertility. Many of these effects are severe and sometimes irreversible [98-100]. A considerable number of metabolic and atrophogenic effects of Gcs are due to their catabolic activity in peripheral organs/tissues, in which protein degradation and lipolysis are induced to stimulate glucocneogenesis in liver and to maintain high blood glucose levels $[12,46]$. These effects involve activation of genes encoding gluconeogenetic enzymes, such as glucose6-phosphatase, phosphoenolpyruvate carboxykinase $(P E P C K)$, tyrosine aminotransferase as well as fatty acid synthase [12, 46, 64], linking many adverse Gcs effects to GR TA. In addition, we and others found that the induction of GR target gene REDD1 (regulated in development and DNA damage response 1) is central to the atrophogenic effects of Gcs in skin, subcutaneous adipose and muscle [101, 102]. Importantly, REDD1 KO animals appeared to be protected against Gcs-induced skin atrophy and muscle waste [101, 103].

Although CpdA side effects during chronic in vivo treatment remain to be comprehensively analyzed, our results and reports by others, indicate that $\mathrm{CpdA}$ induces fewer adverse effects both in control animals and in animal models of diabetes, rheumatoid arthritis, osteoporosis, and Duchene muscle dystrophy when compared to Ges $[67,73,104,105]$. Indeed, in contrast to Gcs, CpdA did not induce key liver gluconeogenic enzymes, glucose-6phosphatase and PEPCK, did not affect hepatic glycogen formation and, as a result did not induce hyperglycemia and hyperinsulinemia after systemic chronic animal treatment $[64,106]$. It is important to note that although decreased $\beta$-cell insulin production and insulin resistance induced by Gcs may lead to the induction of type II diabetes or aggravation of pre-existing diabetes in patients [47], CpdA did not impair glucose metabolism, suggesting a reduced risk for induced type II diabetes by this GR ligand. Furthermore, CpdA was effective in the prevention and treatment of experimental inflammatory diabetes, which resembles type I diabetes in patients [73].

In contrast to steroids, $\mathrm{CpdA}$ did not induce muscle waste when it was used systemically in $m d x$ mice [67]. $\mathrm{CpdA}$ also did not induce skin atrophy in rats and mice when applied topically [107, 108], which we have correlated with its inability to induce atrophogene REDD1 in skin (Budunova, Haegeman, unpublished). In addition, the inhibitory effect of CpdA on collagen type I and III gene expression in skin, the key molecular change related to atrophy in dermis, was favorably diminished when compared to Gcs $[107,108]$.

Chronic administration of Ges also leads to bone loss and osteoporosis due to reduced bone turnover, induction of osteoblast and osteocyte apoptosis, negative effects on Collagen 1 and Runx2, genes directly involved in bone formation, as well as activation of osteoclasts via 
activation of RANKL and osteopontin genes [12,67]. The negative effects of $\mathrm{CpdA}$ on the bone metabolism were significantly weaker compared to Gcs in both newborn and adult mice [67, 104, 105].

Exogenous Gcs suppress the hypothalamic pituitary adrenal (HPA) axis, a major component of the neuroendocrine system, which controls stress adaptation and many body functions, including the immune response, mood and emotions, energy storage, while also regulating the biosynthesis of corticosteroids via $\mathrm{ACTH}$ in the adrenals [12]. ACTH is the key regulatory hormone in the HPA feedback loop, and its expression is negatively regulated by Gcs [12]. It is interestingly to note that even though GR TR by CpdA is overall very efficient, CpdA did not affect the HPA axis significantly as was assessed by the lack of changes in corticosterone and $\mathrm{ACTH}$ serum levels [63, 64].

It is however, important to state that CpdA has some limitations possibly due to its restricted chemical stability. CpdA has a relatively narrow therapeutic window and when used at high doses $(\sim 15 \mathrm{mg} / \mathrm{kg})$ for longer periods it may gradually induce apoptosis via GR-independent metabolites $[8,64]$. Although the anti-cancer effect of CpdA in the lymphoma xenograft model was achieved at lower doses (Fig. 3C), without inducing significant adverse effects during 4-6 wk animal treatment, the treatment of inflammatory diseases in animal models are reported to require higher doses of CpdA [62, 63, 65, 66].

Thus, in our ongoing work we have initiated synthesis of more stable SEGRA using CpdA as a prototype. To date, we and others have used a racemic Compound A for all in vitro and in vivo studies, even though it is known that enantiomers of chiral molecules including steroid receptor ligands often exhibit different chemical and biological properties [109, 110]. Thus, alternative approaches to improve CpdA ligand binding and pharmacological properties could involve its synthesis as an enantiopure compound.

\section{CONCLUSIONS}

In this review, we summarized the results of 10 years of research collaboration between several academic organizations: Stellenbosch University (S. Africa), University of Ghent (Belgium), Northwestern University (Chicago, USA) and the Blokhin Cancer Center (Moscow, Russia), that led not only to the identification of CpdA as a unique SEGRA but also to the characterization of its ligand properties as well as its anti-inflammatory and anti-cancer activities. These studies unraveled the unusual biological properties of $\mathrm{CpdA}$, but also provided a greater understanding of the mechanisms underlying the therapeutic and adverse effects of Gcs. To date no other SEGRA has been shown to exhibit the distinct profile of a dissociating GR ligand as has CpdA both in vitro and in vivo - preventing GR dimerization and subsequent TA, while switching GR activity towards TR. We also showed that CpdA is a dual GR/AR ligand and can act as an anti-inflammatory anti-androgen. The very beneficial pharmacological profile of CpdA can be attributed to its properties as a GR ligand retaining the therapeutic antiinflammatory and anti-cancer potential of Gcs, while inducing fewer side effects. CpdA is furthermore less likely to induce patient resistance as it does not activate the major mechanisms of cell desensitization typical for Gcs. Overall, these properties make CpdA and its prospective derivatives very attractive candidates for clinical applications in the treatment of various inflammatory and autoimmune diseases such as rheumatoid arthritis, asthma and type I diabetes, neuropathy, muscle dystrophies as well as cancer, especially in combinational chemotherapy.

\section{ACKNOWLEDGMENTS AND FUNDING}

The research was supported by Northwestern Memorial Foundation and NUCATS Dixon Translational Research Grants innovation award, Robert H. Lurie Comprehensive Cancer Center - Wendy Will Case Research Gift, and P30CA090386 NU SPORE in Prostate Cancer (to IB); ACS Illinois division Research Award Program (to AY); UICC Yamagiwa-Yoshida Memorial International Cancer Study Grant, Russian Foundation for Basic Research grant \#15-04-04006, Dynasty Foundation Fellowship (to EL); University of Stellenbosch, The Counsel for Scientific and Industrial Research (CSIR) of SA and the National Research Foundation (NRF) of SA, DRD research Travel Fund (to ACS and PS).

\section{CONFLICTS OF INTEREST}

$$
\text { No, there is no conflict of interest. }
$$

\section{Abbreviations}

AP-1, activator protein 1; AR, androgen receptor; BZ, Bortezomib; CIA, collagen-induced arthritis; CpdA, Compound A; DHT, dihydrotestosterone; EAE, experimental autoimmune encephalomyelitis; EAN, experimental autoimmune neuritis; FKBP51, FK506 binding protein 5; FRET, fluorescence resonance energy transfer; Gcs, glucocorticoids; GILZ, glucocorticoidinduced leucine zipper; GR, glucocorticoid receptor; GRE, glucocorticoid responsive element; IFN, interferon; IL, interleukin; NF- $\mathrm{KB}$, nuclear factor kappa B; REDD1, regulated in development and DNA damage response 1; SEGRA, selective glucocorticoid receptor activator; STAT, signal transducer and activator of transcription; TA, transactivation; T-bet, T-box expressed in T cells; TF, transcription factor; Th, T helper; TNF, tumor necrosis factor; TR, transrepression. 


\section{REFERENCES}

1. Newton R. Molecular mechanisms of glucocorticoid action: what is important? Thorax. 2000; 55:603-613.

2. Buckingham JC. Glucocorticoids: exemplars of multitasking. British journal of pharmacology. 2006; 147:S258-268.

3. Whitehouse MW. Anti-inflammatory glucocorticoid drugs: reflections after 60 years. Inflammopharmacology. 2011; 19:1-19.

4. Miner JN, Hong MH, Negro-Vilar A. New and improved glucocorticoid receptor ligands. Expert opinion on investigational drugs. 2005; 14:1527-1545.

5. Rosen J, Miner JN. The search for safer glucocorticoid receptor ligands. Endocrine reviews. 2005; 26:452-464.

6. Stahn C, Lowenberg M, Hommes DW, Buttgereit F. Molecular mechanisms of glucocorticoid action and selective glucocorticoid receptor agonists. Molecular and cellular endocrinology. 2007; 275:71-78.

7. Lowenberg M, Stahn C, Hommes DW, Buttgereit F. Novel insights into mechanisms of glucocorticoid action and the development of new glucocorticoid receptor ligands. Steroids. 2008; 73:1025-1029.

8. De Bosscher K. Selective Glucocorticoid Receptor modulators. The Journal of steroid biochemistry and molecular biology. 2010; 120:96-104.

9. http://clinicaltrials.gov NCT00944632 In.

10. http://clinicaltrials.gov NCT01393639. In.

11. Botschantzev V. A synopsis of Salsola (Chenopodiaceae) from South and South-West Africa. Kew Bulletin. 1974; 29:597-614.

12. Kleiman A, Tuckermann JP. Glucocorticoid receptor action in beneficial and side effects of steroid therapy: lessons from conditional knockout mice. Molecular and cellular endocrinology. 2007; 275:98-108.

13. De Lange M. Prolonged gestation in karakul ewes in South West Africa. Proc 4th Intemat Congress Anim Reprod The Hague. 1961; 3:590-592.

14. Basson PA, Morgenthal JC, Bilbrough RB, Marais JL, Kruger SP, van der Merwe JL. "Grootlamsiekte", a specific syndrome of prolonged gestation in sheep caused by a shrub Salsola tuberculata (Fenzl ex Moq) Schinz var. tomentosa C. A. Smith ex Aellen. The Onderstepoort journal of veterinary research. 1969; 36:59-103.

15. Gibbs GE, Welman WG, Retief E, Immelman KI, Germishuizen G, Pienaar B.J, van Wyk M, Nicholas A. List of species of southern African plants, Ed. 2, Part 2. Memoirs of the Botanical Survey of South Africa. 1987; 56.

16. Wheeler OH. The Girard reagents. Chem Reviews. 1962; 62:205-221.

17. Van der Merwe KJ, Hofmeyr J-HS, Swart P, Parkin DP, Rossouw J, Hartshome J, Van Rensburg SJ, Morgenthal JC, Basson PA. Natural products affecting the gestation period of sheep and their mode of action. S Afr J Sci 72. 1976; $72: 184$.

18. Swart P, Todres PC, Swart AC, Van der Merwe KJ. Microassay for sheep 11 beta-hydroxylase activity using highperformance liquid chromatography for steroid analysis. Journal of chromatography. 1988; 442:424-430.

19. Louw A, Allie F, Swart AC, Swart P. Inhibition of cytochrome P450c11 by biogenic amines and an aziridine precursor, 2-(4-acetoxyphenyl)-2-chloro-N-methylethylammonium chloride. Endocrine research. 2000; 26:729-736.

20. Louw A, Swart P. Salsola tuberculatiformis Botschantzev and an aziridine precursor analog mediate the in vivo increase in free corticosterone and decrease in corticosteroid-binding globulin in female Wistar rats. Endocrinology. 1999; 140:2044-2053.

21. Swart P, van der Merwe KJ, Swart AC, Todres PC, Hofmeyr JH. Inhibition of cytochrome P-450(11)beta by some naturally occurring acetophenones and plant extracts from the shrub Salsola tuberculatiformis. Planta medica. 1993; 59:139-143.

22. Louw A, Swart P, de Kock SS, van der Merwe KJ. Mechanism for the stabilization in vivo of the aziridine precursor -(4-acetoxyphenyl)-2-chloro-N-methylethylammonium chloride by serum proteins. Biochemical pharmacology. 1997; 53:189-197.

23. Adcock IM. Glucocorticoid-regulated transcription factors. Pulmonary pharmacology \& therapeutics. 2001; 14:211-219.

24. Necela BM, Cidlowski JA. Mechanisms of glucocorticoid receptor action in noninflammatory and inflammatory cells. Proceedings of the American Thoracic Society. 2004; 1:239-246.

25. Barnes PJ. Glucocorticosteroids: current and future directions. British journal of pharmacology. 2011; 163:29-43.

26. De Bosscher K, Van den Berghe W, Haegeman G. The interplay between the glucocorticoid receptor and nuclear factor-kappaB or activator protein-1: molecular mechanisms for gene repression. Endocrine reviews. 2003; 24:488-522.

27. Beato M, Herrlich P, Schutz G. Steroid hormone receptors: many actors in search of a plot. Cell. 1995; 83:851-857.

28. Yudt MR, Cidlowski JA. The glucocorticoid receptor: coding a diversity of proteins and responses through a single gene. Molecular endocrinology. 2002; 16:1719-1726.

29. Lavery DN, McEwan IJ. Structure and function of steroid receptor AF1 transactivation domains: induction of active conformations. The Biochemical journal. 2005; 391:449-464.

30. Vandevyver S, Dejager L, Libert C. On the trail of the glucocorticoid receptor: into the nucleus and back. Traffic. 2012; 13:364-374.

31. Davies TH, Ning YM, Sanchez ER. A new first step in activation of steroid receptors: hormone-induced switching 
of FKBP51 and FKBP52 immunophilins. The Journal of biological chemistry. 2002; 277:4597-4600.

32. Barnes PJ. Corticosteroid effects on cell signalling. Eur Respir J. 2006; 27:413-426.

33. De Bosscher K, Van den Berghe W, Haegeman G. Crosstalk between nuclear receptors and nuclear factor kappaB. Oncogene. 2006; 25:6868-6886.

34. Ratman D, Van den Berghe W, Dejager L, Libert C, Tavernier J, Beck IM, De Bosscher K. How glucocorticoid receptors modulate the activity of other transcription factors: a scope beyond tethering. Molecular and cellular endocrinology. 2013; 380:41-54.

35. Yemelyanov A, Czwornog J, Gera L, Joshi S, Chatterton RT Jr., Budunova I. Novel steroid receptor phyto-modulator compound a inhibits growth and survival of prostate cancer cells. Cancer research. 2008; 68:4763-4773.

36. Robertson S, Allie-Reid F, Van den Berghe W, Visser K, Binder A, Africander D, Vismer M, De Bosscher K, Hapgood J, Haegeman G, Louw A. Abrogation of glucocorticoid receptor dimerization correlates with dissociated glucocorticoid behavior of compound a. The Journal of biological chemistry. 2010; 285:8061-8075.

37. De Bosscher K, Van den Berghe W, Beck IM, Van Molle W, Hennuyer N, Hapgood J, Libert C, Staels B, Louw A, Haegeman G. A fully dissociated compound of plant origin for inflammatory gene repression. Proceedings of the National Academy of Sciences of the United States of America. 2005; 102:15827-15832.

38. Gossye V, Elewaut D, Van Beneden K, Dewint P, Haegeman G, De Bosscher K. A plant-derived glucocorticoid receptor modulator attenuates inflammation without provoking ligand-induced resistance. Annals of the rheumatic diseases. 2010; 69:291-296.

39. Lesovaya E, Yemelyanov A, Kirsanov K, Popa A, Belitsky G, Yakubovskaya M, Gordon LI, Rosen ST, Budunova I. Combination of a selective activator of the glucocorticoid receptor Compound A with a proteasome inhibitor as a novel strategy for chemotherapy of hematologic malignancies. Cell cycle. 2013; 12:133-144.

40. Beck IM, Drebert ZJ, Hoya-Arias R, Bahar AA, Devos M, Clarisse D, Desmet S, Bougarne N, Ruttens B, Gossye V, Denecker G, Lievens S, Bracke M, et al. Compound A, a selective glucocorticoid receptor modulator, enhances heat shock protein Hsp70 gene promoter activation. PloS one. 2013; 8:e69115.

41. De Bosscher K, Beck IM, Dejager L, Bougarne N, Gaigneaux A, Chateauvieux S, Ratman D, Bracke M, Tavernier J, Van den Berghe W, Libert C, Diederich M, Haegeman G. Selective modulation of the glucocorticoid receptor can distinguish between transrepression of NF-kappaB and AP-1. Cell Mol Life Sci. 2014; 71:143-163.

42. Tanner TM, Verrijdt G, Rombauts W, Louw A, Hapgood JP, Claessens F. Anti-androgenic properties of
Compound A, an analog of a non-steroidal plant compound. Molecular and cellular endocrinology. 2003; 201:155-164.

43. Chebotaev D, Yemelyanov A, Zhu L, Lavker RM, Budunova I. The tumor suppressor effect of the glucocorticoid receptor in skin is mediated via its effect on follicular epithelial stem cells. Oncogene. 2007; 26:3060-3068.

44. Chebotaev D, Yemelyanov A, Budunova I. The mechanisms of tumor suppressor effect of glucocorticoid receptor in skin. Molecular carcinogenesis. 2007; 46:732-740.

45. Yemelyanov A, Czwornog J, Chebotaev D, Karseladze A, Kulevitch E, Yang X, Budunova I. Tumor suppressor activity of glucocorticoid receptor in the prostate. Oncogene. 2007; 26:1885-1896.

46. De Bosscher K, Beck IM, Haegeman G. Classic glucocorticoids versus non-steroidal glucocorticoid receptor modulators: survival of the fittest regulator of the immune system? Brain Behav Immun. 2010; 24:1035-1042.

47. Schäcke H, Docke WD, Asadullah K. Mechanisms involved in the side effects of glucocorticoids. Pharmacology \& therapeutics. 2002; 96:23-43.

48. Vandevyver S, Dejager L, Tuckermann J, Libert C. New insights into the anti-inflammatory mechanisms of glucocorticoids: an emerging role for glucocorticoid-receptor-mediated transactivation. Endocrinology. 2013; 154:993-1007.

49. Schäcke H, Zollner TM, Docke WD, Rehwinkel H, Jaroch S, Skuballa W, Neuhaus R, May E, Zugel U, Asadullah K. Characterization of ZK 245186, a novel, selective glucocorticoid receptor agonist for the topical treatment of inflammatory skin diseases. British journal of pharmacology. 2009; 158:1088-1103.

50. Schäcke H, Berger M, Rehwinkel H, Asadullah K. Selective glucocorticoid receptor agonists (SEGRAs): novel ligands with an improved therapeutic index. Molecular and cellular endocrinology. 2007; 275:109-117.

51. Nixon M, Andrew R, Chapman KE. It takes two to tango: dimerisation of glucocorticoid receptor and its anti-inflammatory functions. Steroids. 2013; 78:59-68.

52. $\mathrm{Hu} \mathrm{X}, \mathrm{Du} \mathrm{S}$, Tunca $\mathrm{C}$, Braden $\mathrm{T}$, Long KR, Lee J, Webb EG, Dietz JD, Hummert S, Rouw S, Hegde SG, Webber RK, Obukowicz MG. The antagonists but not partial agonists of glucocorticoid receptor ligands show substantial side effect dissociation. Endocrinology. 2011; 152:3123-3134.

53. Striz I, Brabcova E, Kolesar L, Sekerkova A. Cytokine networking of innate immunity cells: a potential target of therapy. Clinical science. 2014; 126:593-612.

54. Barnes PJ. Achieving asthma control. Curr Med Res Opin. 2005; 21:S5-9.

55. Oh S, Hwang ES. The role of protein modifications of T-bet in cytokine production and differentiation of $\mathrm{T}$ helper cells. J Immunol Res. 2014; 2014:589672.

56. Oh H, Ghosh S. NF-kappaB: roles and regulation in different CD4(+) T-cell subsets. Immunol Rev. 2013; 252:41-51. 
57. Hoesel B, Schmid JA. The complexity of NF-kappaB signaling in inflammation and cancer. Mol Cancer. 2013; 12:86.

58. Wan YY. GATA3: a master of many trades in immune regulation. Trends Immunol. 2014; 35:233-242.

59. Zhang Y, Gu W, He L, Sun B. Th1/Th2 cell's function in immune system. Adv Exp Med Biol. 2014; 841:45-65.

60. Zhang Y, Gu W, Sun B. TH1/TH2 cell differentiation and molecular signals. Adv Exp Med Biol. 2014; 841:15-44.

61. Liberman AC, Antunica-Noguerol M, Ferraz-de-Paula V, Palermo-Neto J, Castro CN, Druker J, Holsboer F, Perone MJ, Gerlo S, De Bosscher K, Haegeman G, Arzt E. Compound A, a dissociated glucocorticoid receptor modulator, inhibits T-bet (Th1) and induces GATA-3 (Th2) activity in immune cells. PloS one. 2012; 7:e35155.

62. Rauner M, Thiele S, Sinningen K, Winzer M, SalbachHirsch J, Gloe I, Peschke K, Haegeman G, Tuckermann JP, Hofbauer LC. Effects of the selective glucocorticoid receptor modulator compound $\mathrm{A}$ on bone metabolism and inflammation in male mice with collagen-induced arthritis. Endocrinology. 2013; 154:3719-3728.

63. van Loo G, Sze M, Bougarne N, Praet J, Mc Guire C, Ullrich A, Haegeman G, Prinz M, Beyaert R, De Bosscher K. Anti-inflammatory properties of a plantderived nonsteroidal, dissociated glucocorticoid receptor modulator in experimental autoimmune encephalomyelitis. Molecular endocrinology. 2010; 24:310-322.

64. Wust S, Tischner D, John M, Tuckermann JP, Menzfeld C, Hanisch UK, van den Brandt J, Luhder F, Reichardt HM. Therapeutic and adverse effects of a non-steroidal glucocorticoid receptor ligand in a mouse model of multiple sclerosis. PloS one. 2009; 4:e8202.

65. Zhang Z, Zhang ZY, Schluesener HJ. Compound A, a plant origin ligand of glucocorticoid receptors, increases regulatory T cells and M2 macrophages to attenuate experimental autoimmune neuritis with reduced side effects. Journal of immunology. 2009; 183:3081-3091.

66. Reber LL, Daubeuf F, Plantinga M, De Cauwer L, Gerlo S, Waelput W, Van Calenbergh S, Tavernier J, Haegeman G, Lambrecht BN, Frossard N, De Bosscher K. A dissociated glucocorticoid receptor modulator reduces airway hyperresponsiveness and inflammation in a mouse model of asthma. Journal of immunology. 2012; 188:3478-3487.

67. Huynh T, Uaesoontrachoon K, Quinn JL, Tatem KS, Heier CR, Van Der Meulen JH, Yu Q, Harris M, Nolan CJ, Haegeman G, Grounds MD, Nagaraju K. Selective modulation through the glucocorticoid receptor ameliorates muscle pathology in mdx mice. The Journal of pathology. 2013; 231:223-235.

68. Haapakoski R, Karisola P, Fyhrquist N, Savinko T, Wolff H, Turjanmaa K, Palosuo T, Reunala T, Lauerma A, Alenius H. Intradermal cytosine-phosphate-guanosine treatment reduces lung inflammation but induces IFN-gammamediated airway hyperreactivity in a murine model of natural rubber latex allergy. Am J Respir Cell Mol Biol. 2011; 44:639-647.

69. Reuter KC, Grunwitz CR, Kaminski BM, Steinhilber D, Radeke HH, Stein J. Selective glucocorticoid receptor agonists for the treatment of inflammatory bowel disease: studies in mice with acute trinitrobenzene sulfonic acid colitis. The Journal of pharmacology and experimental therapeutics. 2012; 341:68-80.

70. Dewint P, Gossye V, De Bosscher K, Van den Berghe W, Van Beneden K, Deforce D, Van Calenbergh S, Muller-Ladner U, Vander Cruyssen B, Verbruggen G, Haegeman G, Elewaut D. A plant-derived ligand favoring monomeric glucocorticoid receptor conformation with impaired transactivation potential attenuates collagen-induced arthritis. Journal of immunology. 2008; 180:2608-2615.

71. Pugazhenthi S, Zhang Y, Bouchard R, Mahaffey G. Induction of an inflammatory loop by interleukin-1beta and tumor necrosis factor-alpha involves NF-kB and STAT-1 in differentiated human neuroprogenitor cells. PloS one. 2013; 8:e69585.

72. Kim SY, Hwang JS, Han IO. Tunicamycin inhibits Tolllike receptor-activated inflammation in RAW264.7 cells by suppression of NF-kappaB and c-Jun activity via a mechanism that is independent of ER-stress and N-glycosylation. European journal of pharmacology. 2013; 721:294-300.

73. Saksida T, Vujicic M, Nikolic I, Stojanovic I, Haegeman G, Stosic-Grujicic S. Compound A, a selective glucocorticoid receptor agonist, inhibits immunoinflammatory diabetes, induced by multiple low doses of streptozotocin in mice. British journal of pharmacology. 2014; 171:5898-5909.

74. Suttitheptumrong A, Khunchai S, Panaampon J, Yasamut U, Morchang A, Puttikhunt C, Noisakran S, Haegeman G, Yenchitsomanus PT, Limjindaporn T. Compound A, a dissociated glucocorticoid receptor modulator, reduces dengue virus-induced cytokine secretion and dengue virus production. Biochemical and biophysical research communications. 2013; 436:283-288.

75. Rogatsky I, Hittelman AB, Pearce D, Garabedian MJ. Distinct glucocorticoid receptor transcriptional regulatory surfaces mediate the cytotoxic and cytostatic effects of glucocorticoids. Molecular and cellular biology. 1999; 19:5036-5049.

76. Budunova IV, Kowalczyk D, Perez P, Yao YJ, Jorcano JL, Slaga TJ. Glucocorticoid receptor functions as a potent suppressor of mouse skin carcinogenesis. Oncogene. 2003; 22:3279-3287.

77. Buda G, Orciuolo E, Carulli G, Galimberti S, Ghio F, Cervetti G, Pelosini M, Petrini M. Bortezomib with thalidomide plus dexamethasone compared with thalidomide plus doxorubicin and dexamethasone as induction therapy in previously untreated multiple myeloma patients. Acta haematologica. 2013; 129:35-39.

78. Jo JC, Kang BW, Sym SJ, Lee SS, Jang G, Kim S, Lee DH, Kim SW, Lee JS, Suh C. Initial cytoreductive treatment 
with thalidomide plus bolus vincristine/doxorubicin and reduced dexamethasone followed by autologous stem cell transplantation for multiple myeloma. Investigational new drugs. 2011; 29:175-181.

79. Romano A, Chiarenza A, Conticello C, Cavalli M, Vetro C, Di Raimondo C, Cunsolo R, Palumbo GA, Di Raimondo F. Salvage therapy with pegylated liposomal doxorubicin, bortezomib, cyclophosphamide, and dexamethasone in relapsed/refractory myeloma patients. European journal of haematology. 2014; 93:207-213.

80. Oki Y, Westin JR, Vega F, Chuang H, Fowler N, Neelapu S, Hagemeister FB, McLaughlin P, Kwak LW, Romaguera JE, Fanale M, Younes A, Rodriguez MA, et al. Prospective phase II study of rituximab with alternating cycles of hyper-CVAD and high-dose methotrexate with cytarabine for young patients with high-risk diffuse large B-cell lymphoma. British journal of haematology. 2013; 163:611-620.

81. Herr I, Pfitzenmaier J. Glucocorticoid use in prostate cancer and other solid tumours: implications for effectiveness of cytotoxic treatment and metastases. The Lancet Oncology. 2006; 7:425-430.

82. Yano A, Fujii Y, Iwai A, Kawakami S, Kageyama Y, Kihara K. Glucocorticoids suppress tumor lymphangiogenesis of prostate cancer cells. Clinical cancer research: an official journal of the American Association for Cancer Research. 2006; 12:6012-6017.

83. Yemelyanov A, Bhalla P, Yang X, Ugolkov A, Iwadate K, Karseladze A, Budunova I. Differential targeting of androgen and glucocorticoid receptors induces ER stress and apoptosis in prostate cancer cells: a novel therapeutic modality. Cell cycle. 2012; 11:395-406.

84. Richardson PG, Hideshima T, Mitsiades C, Anderson K. Proteasome inhibition in hematologic malignancies. Annals of medicine. 2004; 36:304-314.

85. Goy A, Gilles F. Update on the proteasome inhibitor bortezomib in hematologic malignancies. Clinical lymphoma. 2004; 4:230-237.

86. Wallace AD, Cao Y, Chandramouleeswaran S, Cidlowski JA. Lysine 419 targets human glucocorticoid receptor for proteasomal degradation. Steroids. 2010; 75:1016-1023.

87. Wallace AD, Cidlowski JA. Proteasome-mediated glucocorticoid receptor degradation restricts transcriptional signaling by glucocorticoids. The Journal of biological chemistry. 2001; 276:42714-42721.

88. Zhang L, Insel PA. Bcl-2 protects lymphoma cells from apoptosis but not growth arrest promoted by cAMP and dexamethasone. American journal of physiology Cell physiology. 2001; 281:C1642-1647.

89. Melhem A, Yamada SD, Fleming GF, Delgado B, Brickley DR, Wu W, Kocherginsky M, Conzen SD. Administration of glucocorticoids to ovarian cancer patients is associated with expression of the anti-apoptotic genes SGK1 and MKP1/DUSP1 in ovarian tissues. Clinical cancer research: an official journal of the American Association for Cancer Research. 2009; 15:3196-3204.

90. Isikbay M, Otto K, Kregel S, Kach J, Cai Y, Vander Griend DJ, Conzen SD, Szmulewitz RZ. Glucocorticoid receptor activity contributes to resistance to androgentargeted therapy in prostate cancer. Hormones \& cancer. 2014; 5:72-89.

91. Volden PA, Conzen SD. The influence of glucocorticoid signaling on tumor progression. Brain Behav Immun. 2013; 30:S26-31.

92. Wu W, Chaudhuri S, Brickley DR, Pang D, Karrison T, Conzen SD. Microarray analysis reveals glucocorticoidregulated survival genes that are associated with inhibition of apoptosis in breast epithelial cells. Cancer research. 2004; 64:1757-1764.

93. van Rossum EF, van den Akker EL. Glucocorticoid resistance. Endocrine development. 2011; 20:127-136.

94. Ramamoorthy S, Cidlowski JA. Ligand-induced repression of the glucocorticoid receptor gene is mediated by an NCoR1 repression complex formed by long-range chromatin interactions with intragenic glucocorticoid response elements. Molecular and cellular biology. 2013; 33:1711-1722.

95. Wiederrecht G, Hung S, Chan HK, Marcy A, Martin M, Calaycay J, Boulton D, Sigal N, Kincaid RL, Siekierka JJ. Characterization of high molecular weight FK-506 binding activities reveals a novel FK-506-binding protein as well as a protein complex. The Journal of biological chemistry. 1992; 267:21753-21760.

96. Stechschulte LA, Sanchez ER. FKBP51-a selective modulator of glucocorticoid and androgen sensitivity. Current opinion in pharmacology. 2011; 11:332-337.

97. Chun E, Lee HS, Bang BR, Kim TW, Lee SH, Kim JH, Cho SH, Min KU, Kim YY, Park HW. Dexamethasoneinduced FKBP51 expression in peripheral blood mononuclear cells could play a role in predicting the response of asthmatics to treatment with corticosteroids. Journal of clinical immunology. 2011; 31:122-127.

98. Barnes PJ. Anti-inflammatory actions of glucocorticoids: molecular mechanisms. Clinical science. 1998; 94:557-572.

99. Resche-Rigon M, Gronemeyer H. Therapeutic potential of selective modulators of nuclear receptor action. Current opinion in chemical biology. 1998; 2:501-507.

100. Vayssière BM, Dupont S, Choquart A, Petit F, Garcia T, Marchandeau C, Gronemeyer H, Resche-Rigon M. Synthetic glucocorticoids that dissociate transactivation and AP-1 transrepression exhibit antiinflammatory activity in vivo. Molecular endocrinology. 1997; 11:1245-1255.

101. Baida G, Bhalla P, Kirsanov K, Lesovaya E, Yakubovskaya M, Yuen K, Guo S, Lavker RM, Readhead B, Dudley JT, Budunova I. REDD1 functions at the crossroads between the therapeutic and adverse effects of topical glucocorticoids. EMBO Mol Med. 2015; $7: 42-58$. 
102. Shimizu N, Yoshikawa N, Ito N, Maruyama T, Suzuki Y, Takeda S, Nakae J, Tagata Y, Nishitani S, Takehana K, Sano M, Fukuda K, Suematsu M, et al. Crosstalk between glucocorticoid receptor and nutritional sensor mTOR in skeletal muscle. Cell Metab. 2011; 13:170-182.

103. Britto FA, Begue G, Rossano B, Docquier A, Vernus B, Sar C, Ferry A, Bonnieu A, Ollendorff V, Favier FB. REDD1 deletion prevents dexamethasone-induced skeletal muscle atrophy. Am J Physiol Endocrinol Metab. 2014; 307:E983-993.

104. Thiele S, Ziegler N, Tsourdi E, De Bosscher K, Tuckermann JP, Hofbauer LC, Rauner M. Selective glucocorticoid receptor modulation maintains bone mineral density in mice. Journal of bone and mineral research: the official journal of the American Society for Bone and Mineral Research. 2012; 27:2242-2250.

105. Rauner M, Goettsch C, Stein N, Thiele S, Bornhaeuser M, De Bosscher K, Haegeman G, Tuckermann J, Hofbauer LC. Dissociation of osteogenic and immunological effects by the selective glucocorticoid receptor agonist, compound A, in human bone marrow stromal cells. Endocrinology. 2011; 152:103-112.

106. Gossye V, Elewaut D, Bougarne N, Bracke D, Van Calenbergh S, Haegeman G, De Bosscher K. Differential mechanism of NF-kappaB inhibition by two glucocorticoid receptor modulators in rheumatoid arthritis synovial fibroblasts. Arthritis and rheumatism. 2009; 60:3241-3250.

107. Schoepe S, Schacke H, Asadullah K. Test systems for the determination of glucocorticoid receptor ligand induced skin atrophy. Dermatoendocrinol. 2011; 3:175-179.

108. Klopot A, Baida G, Budunova I. Novel glucocorticoid receptor modulator Compound A inhibits skin inflammation and hyperplasia. Journal of Investigative Dermatology. 2009; 131:S27.

109. Lee TW, Proudfoot JR, Thomson DS. A concise asymmetric route for the synthesis of a novel class of glucocorticoid mimetics containing a trifluoromethyl-substituted alcohol. Bioorg Med Chem Lett. 2006; 16:654-657.

110. Lin CW, Nakane M, Stashko M, Falls D, Kuk J, Miller L, Huang R, Tyree C, Miner JN, Rosen J, Kym PR, Coghlan MJ, Carter G, et al. transActivation and repression properties of the novel nonsteroid glucocorticoid receptor ligand 2,5-dihydro-9-hydroxy-10-methoxy-2,2,4-trimethyl5-(1-methylcyclohexen-3-y1)-1H-[ 1]benzopyrano[3,4-f] quinoline (A276575) and its four stereoisomers. Mol Pharmacol. 2002; 62:297-303.

111. Swart P, Swart AC, Louw A, van der Merwe KJ. Biological activities of the shrub Salsola tuberculatiformis Botsch.: Contraceptive or Stress Alleviator? BioEssays. 2003; 25:612-619. 